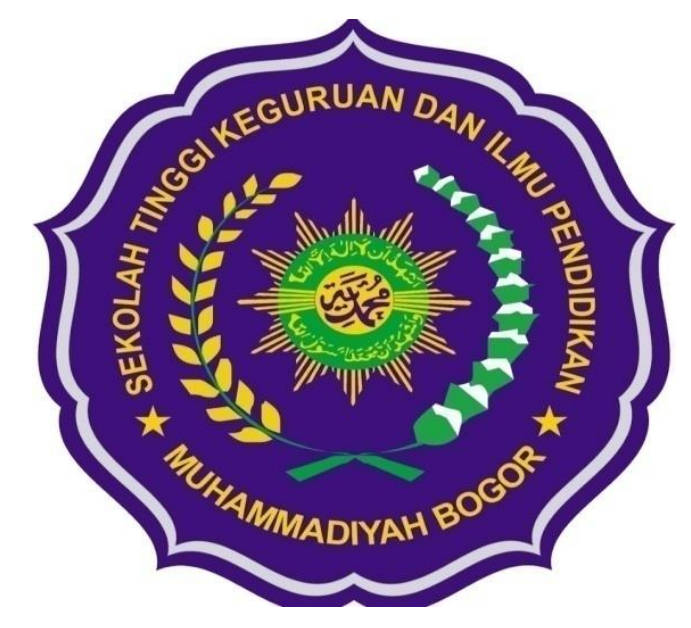

PERTEMUAN/KELOMPOK 3

Dede Kholisoh

Shofwatuttafasiroh

Sri Mutiarawati
0142S1D018003

0142S1D018004

0142S1D018037

PROGRAM STUDI PG PAUD

SEKOLAH TINGGI KEGURUAN DAN ILMU PENDIDIKAN STKIP MUHAMMADIYAH BOGOR

BOGOR

2019 M./1440 H. 


\section{PENGERTIAN, TUJUAN, FUNGSI DAN ASAS-ASAS BIMBINGAN KONSELING ANAK USIA DINI}

\section{A. Tujuan Pembelajaran}

Mahasiswa dapat memahami Pengertian, Tujuan, Fungsi dan Asas-asas Bimbingan Konseling Anak Usia Dini.

B. Materi Pembelajaran

\section{Pengertian Bimbingan Konseling Anak Usia Dini}

a. Definisi Bimbingan

Dalam buku Landasan Bimbingan \& Konseling halaman 5, bimbingan dan konseling merupakan terjemahan dari kata "guidance" dan "counceling" dalam bahasa Inggris. Secara harfiyah istilah "guidance"dari akar kata "guide" berarti (1) mengarahkan (to direct), (2) memandu (to pilot), (3) mengelola (to manage), (4) menyetir (to steer).

Shertzer dan Stone (1971:40) mengartikan bimbingan sebagai “...process of helping an individual understand himself and his world (proses pemberian bantuan kepada individu agar mampu memahami diri dan lingkungannya)."

Sunaryo Kartadinata (1971:3) mengartikannya sebagai “proses membantu individuuntuk mencapai perkembangan optimal." Sementara Rochman Natawidjaja(1987:37) mengartikan bimbingan sebagai "suatu proses pemberian bantuan kepada individu yang dilakukan secara berkesinambungan, supaya individu tersebut bisa memahami dirinya, sehingga dia sanggup mengarahkan dirinya dan dapat bertindak secara wajar sesuai dengan tuntutan dan keadaan lingkungan sekolah, keluarga, masyarakat, dan kehidupan pada umumnya.

b. Definisi Konseling

Dalam buku Landasan Bimbingan \& Konseling, Robinson (M.Surya dan Rochman N. 1986:25) halaman 7, mengartikan konseling adalah semua bentuk hubungan antara dua orang, dimana yang seorang, yaitu klien dibantu untuk lebih mampu menyesuaikan diri secara efektif terhadap dirinya sendiri dan lingkungannya.

Sementara menurut ASCA (American School Counselor Association) mengemukakan bahwa "konseling adalah hubungan tatap muka yang bersifat 
rahasia, penuh dengan sikap penerimaan dan pemberian kesempatan dari konselor kepada klien, konselor mempergunakan pengetahuan dan keterampilannya untuk membantu kliennya mengatasi masalah-masalahnya."

Jadi, bimbingan konseling adalah pelayanan bantuan untuk peserta didik baik individu/kelompok agar mandiri dan berkembang secara optimal dalam hubungan pribadi, sosial, belajar, karir, melalui berbagai jenis layanan dan kegiatan pendukung atas dasar norma-norma yang berlaku.

Meskipun sama-sama berada dalam jalur pendidikan formal, perbedaan rentang usia peserta didik pada tiap jenjang memicu tampilnya kebutuhan pelayanan bimbingan dan konseling yang berbeda-beda pada tiap jenjang pendidikan. Batas ragam kebutuhan antara jenjang yang satu dengan jenjang yang lainnya tidak terbedakan sangat tajam. Disisi lain, perbedaan yang lebih signifikan, juga tampak hal lain pengaturan birokrasi, seperti di taman kanakkanak sebagian besar tugas konselor ditangani langsung oleh guru kelas taman kana-kanak.

Pada jenjang taman kana-kanak di Indonesia, tidak ditemukan posisi structural bagi konselor. Pada jenjang ini, layanan bimbingan dan konselinglebih bersifat preventif dan mengembangkan berbagai aspek serta potensi anak. Secara umum, pelaksanaan dalam bimbingan konseling yang perlu dilakukan oleh konselor jenjang taman kanak-kanak membutuhkan alokasi waktu yang besar dibandingkan jenjang pendidikan yang lebih tinggi.

\section{Tujuan Bimbingan Konseling}

a. Memungkinkan anak menghadapi masalah emosionalyang menyakitinya.

b. Memungkinkan anak memperoleh tingkat keharmonisan dalam pikiran, emosi, dan tingkah laku.

c. Memungkinkan anak merasa nyaman dengan dirinya sendiri.

d. Memungkinkan anak menerima keterbatasannya dan kekuatannya serta merasa oke dengannya.

e. Memungkinkan anak mengubah tingkah laku yang mempunyai akibat negative. 
f. Memungkinkan anak berfungsi dengan nyaman dan beardaptasi dengan lingkungan eksternalnya (misalnya, di rumah dan di sekolah).

g. Memaksimalkan kesempatan bagi anak tersebut untuk mengejar tonggak perkembangannya.

\section{Fungsi dan Asas-asas Bimbingan Konseling}

a. Fungsi Bimbingan Konseling

1. Fungsi Pemahaman, yaitu fungsi bimbingan dan konseling membantu konseli agar memiliki pemahaman terhadap dirinya (potensinya) dan lingkungan (pendidikan, pekerjaan, dan norma agama).

2. Fungsi Preventif, yaitu fungsi yang berkaitan dengan upaya konselor untuk senantiasa mengantisipasi berbagai masalah yang mungkin terjadi dan berupaya untuk mencegahnya, supaya tidak dialami oleh konseli.

3. Fungsi Pengembangan, yaitu fungsi bimbingan dan konseling yang sifatnya lebih proaktif dari fungsi-fungsi lainnya.

4. Fungsi Penyembuhan, yaitu fungsi bimbingan dan konseling yang bersifat kuratif.

5. Fungsi Penyaluran, yaitu fungsi bimbingan dan konseling dalam membantu konseli memilih kegiatan ekstrakurikuler, jurusan atau program studi, dan memantapkan penguasaan karir atau jabatan yang sesuai dengan minat, bakat, keahlian dan ciri-ciri kepribadian lainnya.

6. Fungsi Adaptasi, yaitu fungsi membantu para pelaksana pendidikan, kepala sekolah/Madrasah dan staf, konselor, dan guru untuk menyesuaikan program pendidikan terhadap latar belakang pendidikan,minat, kemampuan, dan kebutuhan konseli.

b. Asas-asas Bimbingan Konseling

Penyelenggaraan layanan dan kegiatan pendukung bmbingan dan konseling selain dimuati oleh fungsi dan didasarkan pada prinsip-prinsip tertentu, juga dituntut untuk memenuhi sejumlah asas bimbingan, pemenuhan asas-asas bimbingan itu akan memperlancar pelaksanaan dan lebih menjamin keberhasilan layanan/kegiatan, sedangkan pengingkarannya akan dapat menghambat bahkan 
menggagalkan pelaksanaan, serta mengurangi atau mengaburkan hasil layanan/kegiatan bimbingan dan konseling itu sendiri.

Adapun asas-asas dari bimbingan dan konseling tersebut adalah:

\section{Asas Kerahasiaan}

Asas ini menuntut dirahasiakannya segenap data dan keterangan peserta didik (klien) yang menjadi sasaran layanan, yaitu data atau keterangan yang tidak boleh dan tidak layak diketahui orang lain.

\section{Asas Kesukarelaan}

Asas yang menghedaki adanya kesukaan dan kerelaan peserta didik (klien) mengikuti/menjalani layanan/kegiatan yang diperuntukan baginya.

\section{Asas Keterbukaan}

Asas yang menghendaki agar peserta didik yang menjadi sasaran layanan/kegiatan bersikap terbuka dan tidak berpura-pura, baik dalam memberikan keterangan tentang dirinya sendiri maupun dalam menerima berbagai informasi dan materi dari luar yang berguna bagi pengembangan dirinya.

\section{Asas Kegiatan}

Asas yang menghendaki agar peserta didik yang menjadi sasaran layanan dapat berpartisipasi aktif didalam penyelenggaraan/kegiatan bimbingan.

\section{Asas Kemandirian}

Asas yang menunjukan pada tujuan umum bimbingan dan konseling yaitu peserta didik sebagai sasaran layanan/kegiatan bimbingan dan konseling diharapkan menjadi individu-individu yang mandiri, dengan ciri mengenal diri sendiri dan lingkungannya, mampu mengambil keputusan, mengarahkan, serta mewujudkan diri sendiri.

\section{Asas Kekinian}

Asas yang menghendaki agar objek sasaran layanan bimbingan dan konseling yakni permasalahan yang dihadapi peserta didik/klien dalam kondisi sekarang.

\section{Asas Kedinamisan}

Asas yang menghendaki agar isi layanan terhadap sasaran layanan (peserta didik/klien) hendaknya selalu bergerak maju, tidak monoton, dan 
terusberkembang serta berkelanjutan sesuai dengan kebutuhan dan tahap perkembangannya dari waktu ke waktu.

8. Asas Keterpaduan

Asas yang menghendaki agar berbagai layanan dan kegiatan bimbingan dan konseling, baik yang dilakukan oleh guru pembimbing maupun pihak lain, saling menunjang, harmonis dan terpadukan.

\section{Asas Kenormatifan}

Asas yang menghendaki agar segenap layanan dan kegiatan bimbingan dan konseling didasarkan pada norma-norma, baik norma agama, hukum, peraturan, adat istiadat, ilmu pengetahuan dan kebiasaan-kebiasaan yang berlaku.

10. Asas Keahlian

Asas yang menghendaki agar layanan dan kegiatan bimbingan dan konseling diselenggarakan atas dasar kaidah-kaidah professional. Dalam hal ini kaidah pelaksana layanan dan kegiatan bimbingan dan konselinglainnya hendaknya tenaga yang benar-benar ahli dalam bimbingan dan konseling.

11. Asas Alih Tangan Kasus

Asas yang menghendaki agar pihak-pihak yang tidak manpu menyelengarakan layanan bimbingan dan konseling secara tepat dan tuntas atas suatu permasalahan peserta didikkiranya dapat mengalih-tangankan kepada pihak yang lebih ahli. Guru pembimbing (konselor) dapat menerima alih tangan kasus dari orang tua, guru-guru lain, atau ahli lain. Demikian pula sebaliknya guru pembimbing (konselor) dapat mengalih tangankan kasus kepada pihak lain yang lebih kompeten, baik yang berada di dalam lembaga sekolah maupun di luar sekolah.

\section{Asas Tut Wuri Handayani}

Asas yang menghendaki agar pelayanan bimbingan dan konseling secara keseluruhan dapat menciptakan suasana mengayomi (memberikan rasa aman), mengembangkan keteladanan dan memberikan rangsangan dan dorongan, serta kesempatan seluas-luasnya kepada peserta didik (klien) untuk maju. 


\section{Kesimpulan}

Bimbingan konseling adalah pelayanan bantuan untuk peserta didik baik individu/kelompok agar mandiri dan berkembang secara optimal dalam hubungan pribadi, sosial, belajar, karir, melalui berbagai jenis layanan dan kegiatan pendukung atas dasar norma-norma yang berlaku.

Bimbingan konseling bertujuan agar anak dapat menghadapi masalah emosionalnya, memiliki tingkat keharmonisan dalam tingkah laku, emosi dan pikiran sehingga anak merasa nyaman dengan dirinya sendiri, Menerima keterbatasannya dan mengubah tingkah laku anak yang mempunyai akibat negative menjadi positif. 
D. Soal dan kunci jawaban

I. Pilihan ganda

1. Manakah yang tidak termasuk tujuan bimbingan konseling ?

a. Memungkinkan anak merasa nyaman dengan diri sendiri

b. Memungkinkan anak memperoleh tingkat keharmonisan dalam pikiran, emosi dan tingkah laku

c. Meminimalisir kesempatan bagi anak tersebut untuk mengejar tonggak perkembangannya

d. Memungkinkan anak mengubah tingkah laku yang mempunyai akibat negative

e. Semua jawaban benar

2. Fungsi yang berkaitan dengan upaya konselor untuk senantiasa mengantisipasi berbagai masalah yang mungkin terjadi dan berupaya untuk mencegahnya, supaya tidak dialami oleh konseli.

Fungsi bimbingan konseling apkahah yang terdapat pada pernyataan tersebut?
a. Fungsi Penyaluran
b. Fungsi Preventif
c. Fungsi Pengembangan
d. Fungsi Adaptasi
e. Fungsi Pemahaman

3. Fungsi penyembuhan yaitu fungsi bimbingan konseling yang bersifat ?
a. Potensial
b. Proaktif
c. Preventif
d. Kuratif
e. Positif

4. Asas yang menghendaki agar pelayanan bimbingan dan konseling secara keseluruhan dapat menciptakan suasana mengayomi (memberikan rasa aman) mengembangkan pelayanan dan memberikan rangsangan dan dorongan serta kesempatan seluas-luasnya kepada peserta didik (klien) untuk maju. 
Pernyataan asas-asas bimbingan konseling tersebut, termasuk dalam asas?
a. Asas Kerhasiaan
b. Asas Keterbukaan
c. Asas Kekinian
d. Asas Tut Wuri Handayani
e. Asas Kenormatifan

5. Memungkinkan anak menghadapi masalah emosional yang menyakitinya dan memungkinkan anak menerima keterbatasannya dan kekuatannya serta merasa aman dengannya. Hal tersebut termasuk kedalam?
a. Pengertian bimbingan konseling
b. Tujuan bimbingan konseling
c. Asas bimbingan konseling
d. Fungsi bimbingan konseling
e. a dan d benar

6. Asas yang menghendaki agar peserta didik yang menjadi sasaran layanan dapat berpartisipasi aktif didalam penyelenggaraan/kegiatan bimbingan merupakan asas?
a. Kegiatan
b. Kenormatifan
c. Kedinamisan
d. Kekinian
e. Keterpaduan

7. “...process of helping an individual understand himself and his world. Merupakan pendapat yang dikemukakan oleh ?
a. Sunaryo Kartadinata
b. Hurlock
c. Rochman Natawidjaja
d. Shertzer dan Stone
e. Smith and Pellegrini

8. Bimbingan dan konseling membantu konseli agar memiliki pemahaman terhadap dirinya (potensinya) dan lingkungan. Hal ini merupakan fungsi dari ? 

a. Kenormatifan
b. Pemahaman
c. Preventif
d. Penyaluran
e. Penyembuhan

9. konseling adalah hubungan tatap muka yang bersifat rahasia, penuh dengan sikap penerimaan dan pemberian kesempatan dari konselor kepada klien, konselor mempergunakan pengetahuan dan keterampilannya untuk membantu kliennya mengatasi masalah-masalahnya. Pendapat diatas dikemukakan oleh ?
a. ASCA
b. Shertzer and Stone
c. Sunaryo Kartadinata
d. Rochman Natawidjaja
e. Hurlock

10. Apa yang dimaksud asas Kedinamisan?

a. Asas yang menghendaki agar peserta didik yang menjadi sasaran layanan/kegiatan bersikap terbuka dan tidak berpura-pura, baik dalam memberikan keterangan tentang dirinya sendiri mauoun dalam menerima berbagai informasi dan materi dari luar yang berguna bagi pengembangan dirinya.

b. Asas yang menghendaki agar isi layanan terhadap sasaran layanan (peserta didik/klien) hendaknya selalu bergerak maju, tidak monoton, dan terus berkembang serta berkelanjutan sesuai dengan kebutuhan dan tahap perkembangannya dari waktu ke waktu.

c. Asas yang menghendaki agar segenap layanan dan kegiatan bimbingan dan konseling didasarkan pada norma-norma, baik norma agama, hukum, peraturan, adat istiadat, ilmu pengetahuan dan kebiasaankebiasaan yang berlaku.

d. Asas yang menghedaki adanya kesukaan dan kerelaan peserta didik (klien) mengikuti/menjalani layanan/kegiatan yang diperuntukan baginya. 
e. Asas yang menghendaki agar objek sasaran layanan bimbingan dan konseling yakni permasalahan yang dihadapi peserta didik/klien dalam kondisi sekarang.

\section{Essay}

1. Jelaskan fungsi bimbingan konseling !

2. Jelaskan pengertian konseling menurut ASCA !

3. Jelaskan pengertian bimbingan menurut Sunaryo Kartadinata !

4. Apa yang dimaksud dengan asas kenormatifan ?

5. Apa yang dimaksud dengan asas kedinamisan?

Jawaban

1. c

6. a

2. b

7. d

3. d

8. $\mathrm{b}$

4. d

9. a

5. b 10. B

1. Yaitu fungsi yang berkaitan dengan upaya konselor untuk senantiasa mengantisipasi berbagai masalah yang mungkin terjadi dan berupaya untuk mencegahnya supaya tidak dialami oleh konseli.

2. Adalah hubungan tatap muka yang bersifat rahasia,penuh dengan sikap penerimaan dan pemberian kesempatan dari konselor kepada konseli.

3. Adalah proses membantu indivdu untuk mencapai perkembangan optimal

4. Yaitu asas yang menghendaki agar segenap layanan dan kegiatan bimbingan dan konseling didasarkan pada norma-norma, baik norma agama, hukum, peraturan, adat istiadat, ilmu pengetahuan dan kebiasaankebiasaan yang berlaku.

5. Yaitu asas yang menghendaki agar isi layanan terhadap sasaran layanan (peserta didik/klien) hendaknya selalu bergerak maju, tidak monoton,dan terus berkembang serta berkelanjutan sesuai dengan kebutuhan dan tahap perkembangannya dari waktu ke waktu. 
Arsyad, Arsyad, \& Sulfemi, Wahyu Bagja. (2013). Pengaruh Persepsi Guru Tentang Kemampuan Manajerial Kepala Sekolah dan Kecerdasan Emosional Guru Terhadap Kinerja Guru (Studi Kasus Di SMK Muhammadiyah 6 Kabupaten Bogor). Fascho 2 (1), 1-9

Arsyad, Arsyad, \& Sulfemi, Wahyu Bagja. (2016). Pengembangan Keprofesian Berkelanjutan (PKB) Bagi Guru Melalui Program Induksi Guru Pemula (PIGP). Seminar Nasional STKIP Muhammadiyah Bogor.2 (2), 12-22

Arsyad, Arsyad dan Sulfemi, Wahyu Bagja. (2018) Metode Role Playing Berbantu Media Audio Visual Pendidikan dalam Meningkatkan Belajar IPS. Jurnal Pendidikan Ilmu Pengetahuan Sosial Indonesia. 3 (2). 41 46.

Arsyad, Arsyad dan Sulfemi, Wahyu Bagja (2019). Korelasi Penguasaan Materi Pembelajaran Oleh Guru Dengan Motivasi Belajar Siswa Mata Pelajaran Administrasi Perkantoran di SMK Pelita Bogor. Edutecno. 20 (2), 1-20.

Yusuf,Syamsu,JuantikaNurihsan.(2016).LandasanBimbingan\&Konseling. Bandung:PTRemajaRosdakarya

Sultoni, Wahyu Bagja, (2007). Ilmu Sosial Dasar. Bogor : STKIP Muhammadiyah

Sudirman, Sudirman \& Sulfemi, Wahyu Bagja. (2010). Korelasi Antara Konsep Diri Guru dengan Profesionalisme Guru di SMA Negeri 1 Pamijahan Kabupaten Bogor. Edutecno 2 (2), 10-19.

Sulfemi, Wahyu Bagja. (2015). Kemampuan Pedagogik Guru. Prosiding Seminar Nasional. STKIP Muhammadiyah Bogor 1. (1). 71-83

Sugiri, Sugiri \& Sulfemi, Wahyu Bagja. (2011). Pendidikan Multi Kultur di Sekolah Berbasis Keagamaan. Edutecno. 3 (2), 11-20

Sulfemi, Wahyu Bagja. (2016). Kompetensi Profesionalisme Guru Indonesia dalam Menghadapi MEA. Prosiding Seminar Nasional STKIP Muhammadiyah Bogor. 1 (1), 62-77.

Sulfemi, Wahyu Bagja. (2016). Modul Pembelajaran Ilmu Sosial dan Budaya Dasar. Bogor : STKIP Muhammadiyah Bogor

Sulfemi, Wahyu Bagja. (2016). Perundang-Undangan Pendidikan. Bogor : Program Studi Administrasi Pendidikan STKIP Muhammadiyah Bogor

Sulfemi, Wahyu Bagja (2019). Model Pembelajaran Kooperatif Mind Mapping Berbantu Audio Visual Dalam Meningkatkan Minat, Motivasi dan Hasil Belajar IPS. Jurnal Pendidikan Ilmu Pengetahuan Sosial Indonesia (PIPSI). 4 (1), $13-19$.

Sulfemi, Wahyu Bagja., \& Yuliana, Desi. (2019). Penerapan Model Pembelajaran Discovery Learning Meningkatkan Motivasi dan Hasil Belajar 
Pendidikan Kewarganegaraan. Jurnal Rontal Keilmuan Pancasila dan Kewarganegaraan. 5 (1), 17-30.

Sulfemi, Wahyu Bagja dan Mayasari, Nova. (2019). The Use of Audio Visual Media in Value Clarification Technique to Improvestudent Learning Outcomesin Social Studies. Jurnal Pendidikan. 20 (1), 53-68.

Sulfemi, Wahyu Bagja. (2019). Asosiatif Layanan Tenaga Perpustakaan Sekolah Dengan Motivasi Membaca Siswa di Kabupaten Bogor. Edutecno. 19 (2), $1-10$.

Yusfiriadi, Yusfiriadi, \& Sulfemi, Wahyu Bagja. (2011). Pemberdayaan Unit Produksi Melalui Pendekatan Manajemen Stratejik di SMK Pertiwi Kabupaten Bogor. Edutecno. 3 (1), 1-10.

Yusfiriadi, Yusfiriadi, \& Sulfemi, Wahyu Bagja. (2012). Penyelewangan Dana Dalam Dunia Pendidikan. Fascho 1 (1), 1-9.

http://makalahpendidikan-sudirman.blogspot.com./2012.02/tujuan-bimbingankonseling.html? $\mathrm{m}=1$

https://purplenitadyah.wordpress.com/2012/05/17/fungsi-prinsip-dan-asasbimbingan-dan-konseling 